\begin{tabular}{|c|c|c|}
\hline$A$ & $\begin{array}{c}\text { International Journal of Current Research } \\
\text { and Academic Review }\end{array}$ & \\
\hline $\begin{array}{l}\text { EXCELLENT } \\
\text { PUBLISHERS } \\
\end{array}$ & 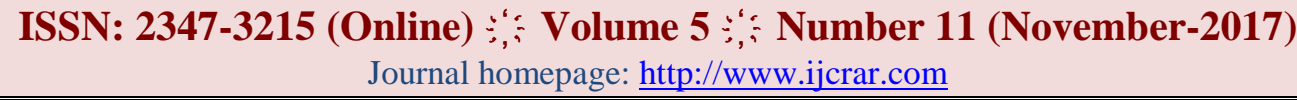 & \\
\hline
\end{tabular}

doi: $\underline{\text { https://doi.org/10.20546/ijcrar.2017.511.011 }}$

\title{
Studies on the Insecticidal Activities of Pseudocedrela kotschyi on Culex quinquefasciatus Larvae and the Maize Weevil (Sitophilus zeamais) Motschulsky
}

\author{
A. Dawet*, D. P. Yakubu and T. M. Meshach \\ Department of Zoology, Faculty of Natural Sciences, University of Jos, Jos, Nigeria \\ *Corresponding author
}

\section{Abstract}

Culex quinquefasciatus is the vector that transmits the causative agent of filariasis which poses a great threat to the world at large. Storage pest are nuisance to farmers because they destroy farm products either in the store or in the farm. In this study, the insecticidal activity of Pseudocedrela kotschyi stem bark extract was tested against the fourth instar larvae of Culex quinquefasciatus and adult Sitophilus zeamais. A total of three hundred and sixty $4^{\text {th }}$ instar larvae of Culex quinquefasciatus were divided into six groups each consisting of three replicates containing twenty larvae each. Groups one to four were each administered one of the following dose: $1000 \mathrm{mg}, 250 \mathrm{mg}, 125 \mathrm{mg}$ and $62.5 \mathrm{mg}$ of the ethanolic stem bark extract of $P$. kotschyi. Group five was treated with a standard drug (permethrin $0.6 \%$ ) and the last group was neither treated with the extract nor the standard drug. The highest concentration $1000 \mathrm{mg}$ of the plant extract had $98.33 \%$ mortality followed by $250 \mathrm{mg}$ which exhibited $61.67 \%, 125 \mathrm{mg}$ with $48.33 \%$ mortality and 62.5 with $25 \%$. There was $100 \%$ mortality in the group treated with standard drug and no mortality in the control. Analysis of variance showed significant difference $(\mathrm{p}<0.05)$ in the mortality of larvae between the different extract levels.The mortality of the Sitophilus zeamais was observed for 7 daysafter exposure. The highest percentage mortality of $53.33 \%$ was recorded inthe weevils treated with $750 \mathrm{mgof}$ the plant extract followed by $1750 \mathrm{mg}$ which had $50 \%$ and the lowest concentration of $500 \mathrm{mg}$ plant extract had the lowest mortality of $33.33 \%$. However, there is no significant difference $(p>0.05)$ between the mortality of the groups administered extract at different concentrations. From the result, it can be tentatively concluded here; based on this research that $P$. kotschyi can act as a bio-pesticide of plant origin which will be less toxic to man and other organisms.
\end{abstract}

\section{Article Info}

Accepted: 15 October 2017

Available Online: 20 November 2017

\begin{tabular}{l} 
Keywords \\
\hline Insecticidal activities, \\
P.kotschyi, \\
Culex quinquefasciatus larvae, \\
Sitophilus zeamais.
\end{tabular}

\section{Introduction}

Mosquito-transmitted diseases remain a major cause of the loss of human life worldwide with more than 700 million people suffering from the diseases annually (Taubes, 1997). C. quinquefasciatus (Diptera: Culicidae) is widelydistributed in tropical and subtropical areas and is the most important vector of filarialparasite Wuchereria bancrofti, although Anopheles gambiae s.l and An. funestus also play arole in selected areas (Maxwell et al., 1990). Culex quinquefasciatus, a vector of lymphatic filariasis is widely distributed in tropical zones with around 120 million people infected wordwide and 44 million people having infected worldwide and 44 
million people having common chronic manifestation (Bernhard et al., 2003). Despite its debilitating effects, lymphatic filariasis is given a very low control priority (Ramarah et al., 2000; Yadouléton et al., 2015).

Apart from mosquito as a nuisance to humanity, insects like the maize weevil (Sitophilus zeamais) and cowpea weevil (Callosobruchus maculatus) also cause great nuisance to humanity by destroying stored grains. The maize weevil (Sitophilus zeamais), known in the United States as the greater rice weevil is a species of beetle in the family curculionidae. It can be found in numerous tropical areas around the world and in the United States and is a major pest of maize. This species attacks both standing crops and stored cereal products, including wheat, rice, sorghum, oats, barley, rye, buck-wheat, peas and cotton seed. (Pest web, 2010). Corn, Zea mays belongs to the family graminae. It is a cereal grass related to wheat, rice, oat and barley, ranking second after wheat and is followed by third-ranking rice in order of world's grain production. This plant is regarded as versatile and with many uses since it can thrive in diverse climates, hence, it is grown in many countries than any other crop. Aside from being one of the major sources of food for both human and animals, it is also processed into various food and industrial products including starches, sweeteners, oil, beverage, industrial alcohol and fuel ethanol. Therefore, the conservation of this grain is essential to have this basic food available on an ongoing bass (Huang and Subramanyam, 2005).

However, post harvest storage of maize is greatly constrained by the pest, Sitophilus zeamais motschulsky. Initial infestations of maize grain occur in the field just before harvest and the insects are carried into the store where the population builds up rapidly (Adedire and Lajide, 2003). Infestations not only cause significant economic losses due to the consumptions of grains, they also result in elevated temperature and moisture conditions that lead to an accelerated growth of molds, including toxigenic species (Maga et al., 2003). The growth of molds leads to the production of aflatoxin.

Stored grains may suffer serious attack from pests (insects, rodents and birds) and pathogens (bacteria and fungi), especially when not protected and when storage hygiene is poor. Amidst other constraints of maize production, insect pests constitute a major threat, destroying approximately $20 \%$ of food produce (Pimental, 2007). The damage caused by post harvest pests is much higher than that caused by other agents like rodents and micro-organisms.
The protection of stored products against attack by insect pests is essential in many countries, particularly those that do not have adequate storage facilities. Control of these pests relies on the widespread use of various synthetic chemical insecticides and fumigants. It has led to a number of serious problems such as environmental pollution, pesticide residue in food grains, pesticide resistance and toxicity to non-target organisms (Cosimi et al., 2009). Botanical pesticides are an important group of naturally occurring, often slow-acting crop protectants that are usually safer to humans and the environment than conventional pesticides and with minimal residual effects. Moreover, the fact that botanical pesticides contain mixtures of biologically active substances, no resistance is developed in pests and pathogens. Therefore, the use of plant pesticides has been recommended ever more as a suitable alternatives of plant protection with minimum negative risks (Isman, 2006; Pavela, 2007).

Pseudocedrela kotschyi has numerous uses in traditional medicine, particularly its bark, roots and leaves. The bark of $P$. Kotschyi contains a bitter non-nitrogenous principle, pseudocedrelin, demonstrated to possess piscidal activity (Oliver-Bever, 1986). P. kotschyi root extracts have been shown to inhibit the In vitro growth and development of the Schizont stage of Plasmodium falciparum and may provide affordable means of treating malaria (Kassim et al., 2009).

The ethanol stem bark extract of $P$. kotschyi reduced the activities of both larvae and adult Dermestes maculatus beetles in feeding and movement during the 7 days exposure (Yakubu et al., 2015). Yadouléton et al., (2015) showed that wild populations of $C x$. quinquefasciatus have developed resistance against pyrethroids, organochlorine and carbamate. There has been an increasing search for edible, cheap, and safe plant materials that will not contaminate food products in acting as grain protectants in small storage systems (Arannilewa, 2002). It is on this basis that the present study was carried out to investigate the insecticidal effects of $P$. Kotschyi against mosquito and maize weevil.

\section{Materials and Methods}

\section{Study area}

The study was conducted in the Undergraduate Laboratory, Department of Zoology, University of Jos, Jos, Nigeria. 


\section{Sample collection}

\section{The Mosquito Larvae}

The larvae of Culex species were identified using the principal characters for mosquito identification (http://entomology.unl.edu/urbanent/mosquito.htm).

Contrary to the Anopheles larvae which lie parallel to the surface of the water, $C x$. quinquefasciatus larvae hang at an angle to the surface of the water. The collection of larvae was carried out as described by Yadouléton et al., (2015). First instar larvae of mosquito larvae was collected from stagnant water from a compound in the University of Jos students' Village Hostel. Zooplanktons and phytoplankton were collected alongside the larvae in large quantity to serve as feed for the larvae and to act as if in their natural environment. Larvae were collected using the dipping on breeding sites and then kept in labeled bottles. In 2-3 days, the $1^{\text {st }}$ instar larvae metamorphosed into the $4^{\text {th }}$ instar larvae.

\section{The maize weevil}

The maize weevil was collected from an old infested stored grain. The weevils were identified based on morphological characters described by Barro and Delong (1964); Hill (1975). The identified weevils were kept in a plastic container covered with muslin cloth along with dried maize grains.

\section{Plant and Extraction}

This was carried out in a similar method as described by (Dawet et al., 2011). Pseudocedrela kotschyi (Plate 1) stem bark was collected from Bwai in Mangu Local Government Area, Plateau State, Nigeria. The stem bark of P.kotschyi was collected and dried in the open air under shade for 7 days and pulverized using mortar and pestle. The pulverized stem bark $(220 \mathrm{~g})$ was soaked in $400 \mathrm{ml}$ absolute ethanol for 72 hours and filtered. The filtrate was then dehydrated in a hot oven at $50 \mathrm{C}$ and the residue was stored at $4 \mathrm{C}$ until use.

\section{Formulation of the test solution}

\section{For the mosquito larvae}

$5 \mathrm{~g}$ of the powdered extract was dissolved in $10 \mathrm{mls}$ of water which became the stock solution to be used in the test. Various milliliters $(\mathrm{ml})$ of the stock were obtained using $0.1-1.0 \mathrm{ml}$ calibrated syringe. These quantities of the measured extract were then added into $50 \mathrm{ml}$ of straw water for each container. The quantities were $2 \mathrm{ml}, 0.5 \mathrm{ml}$, $0.25 \mathrm{ml}, 0.125 \mathrm{ml}$, giving four (4) doses of the extract: $1000 \mathrm{mg}, 250 \mathrm{mg}, 125 \mathrm{mg}$ and $62.5 \mathrm{mg}$ per $50 \mathrm{ml}$ respectively; a standard drug with $0.6 \%$ permethrin and a control.

\section{For the maize weevils}

$15 \mathrm{~g}$ of the powdered extract was dissolved into $30 \mathrm{mls}$ of water. The reason for dissolving in distilled water is to increase the moisture content of the maize grains for penetration of the extract into the grains. This severed as the stock. Various milliliters (ml) of the stock solution were measured using $5 \mathrm{ml}$ calibrated syringe. The concentrations were $3.5 \mathrm{ml}, 3 \mathrm{ml}, 2.5 \mathrm{ml}, 1.5 \mathrm{ml}, 1 \mathrm{ml}$, a standard pesticide containing $2.0 \%$ permethrin and control. These made it five (5) concentrations of the extract of $1750 \mathrm{mg}, 1500 \mathrm{mg}, 1250 \mathrm{mg}, 750 \mathrm{mg}$ and $500 \mathrm{mg}$ respectively.

\section{Insect bioassay}

$50 \mathrm{mls}$ of water each, containing phytoplankton and zooplanktons was added into 18 plastic disposable containers each (Plate 2). Then 20 fourth instar larvae of mosquitoes each was added into each container. They were divided into 6 groups consisting of 3 replicate each. Groups 1-4 were administered $2 \mathrm{ml}, 0.5 \mathrm{ml}, 0.25 \mathrm{ml}$ and $0.125 \mathrm{ml}$ of Pseudocedrela kotschyi plant extract respectively. Group 5 was treated with $2 \mathrm{ml}$ of the standard drug containing $0.6 \%$ permethrin. Group 6 was neither treated with the plant extract nor the standard drug. The mortality of larvae was recorded for three (3) consecutive days.

In another set, $20 \mathrm{~g}$ each of uninfected maize grains was measured into 21 disposable plastic containers each (Plate 3). They were divided into 7 groups consisting of 3 replicates each. Groups 1-5 were administered $3.5 \mathrm{ml}$, $3 \mathrm{ml}, 2.5 \mathrm{ml}, 1.5 \mathrm{ml}$ and $1 \mathrm{ml}$ of the Pseudocedrela kotschyi plant extract respectively. Group 6 was treated with $2 \mathrm{ml}$ of the standard drug containing $2.0 \%$ permethrin. Group 7 was treated with neither the plant extract nor the standard drug. The mortality of the adult weevils was recorded for seven (7) consecutive days.

\section{Determination of the mortality}

The mortality of test organisms was observed and recorded every twenty four hours. Mosquito larvae and adult weevils were considered dead when no response was observed after probing them on their antennae, 
ventral part or the lateral side with a forcep under a hand lens or dissecting microscope. Death larvae and adults were isolated and stored in separate containers as soon as the mortality was observed and recorded.

\section{Statistical analysis}

Data were analyzed using one way analysis of variance (ANOVA). $\mathrm{P}<0.05$ were considered significant.

\section{Results and Discussion}

\section{$\mathrm{LD}_{50}$ of Culex quinquefasciatus Larvae After 24 hours}

The administration of the ethanolic stem bark extract of Pseudocedrela kotschyi at $62.5 \mathrm{mg} / \mathrm{ml}$ did not result to mortality of $C$. quinquefasciatus larvae after $24 \mathrm{hrs}$ ofexposure. However the administration of $125 \mathrm{mg} / \mathrm{ml}$, $250 \mathrm{mg} / \mathrm{ml}$, and $1000 \mathrm{mg} / \mathrm{ml}$ resulted to $18.33 \%, 20 \%$, and $66.67 \%$ mortality of $C$. quinquefasciatus larvae respectively after 24 hours of exposure (Table 1 ).

The $\mathrm{LD}_{50}$, that is, the lethal dose that killed $50 \%$ of the mosquito larvae population in 24 hours was $630.95 \mathrm{mg} / \mathrm{ml}$ (figure 1 ).

The effect of Pseudocedrela kotschyi extract on the three days mortality of Culex quinquefasciatus larvae was recorded as seen in table 2 .

It was observed that the number of mortality increased with increase in the dose of the plant extract. Analysis of variance shows that there was significant difference $(p<0.05)$ between the mortality of the groups.

\section{Effect of $P$. kotschyi ethanolic stem bark extract on Sitophilus zeamais}

The mortality of the Sitophilus zeamais after seven days of administration of the ethanolic extract of Pseudocedrela kotschyi is shown in Table 4.

The result showed that the mortality of weevils was not dose dependent since the percentage mortalityof weevils exposed to plant extract at $750 \mathrm{mg} / \mathrm{ml}$ and $1750 \mathrm{mg} / \mathrm{ml}$ was $53.33 \%$ and $50 \%$ respectively (Table 5).

There was high mortality (100\%) in the group given the standard drug. However, analysis of variance showed that there is no significant difference $(\mathrm{p}>0.05)$ in the mortality of weevils exposed to $P$. kotschyi stem bark extract compared with the control.
The ethanolic stem bark extract of Pseudocedrela kotschyi showed very low to non-effect on Sitophilus zeamais, however, the effect on Culex quinquefasciatus larvae was very significant. It was observed that during the period of the research, developmental processes like, pupation and metamorphosing to adult was not hindered in Culex quinquefasciatus larvae. The high percentage mortality of Culex quinquefasciatus recorded in this study agrees with Mankale (2010) who reported $92.30 \%$ mortality of Culex quinquefasciatus larvae after 24 hours of the administration of 500mg of Neem extract. This results also concord with Gutierrez et al., (2014)whoin their study observed that the three plant Jatropha curcas, Citrus grandis and Tinospora rumphii samples showed larvicidal activity against the dengue-vector, Aedes aegypti mosquito larvae which is manifested by a high percentage of mortality in comparison to those in the control group. The mortality of mosquito larvae between the various concentrations of the plant extracts and the control group was also significantly different at 0.05 level of significance. Furthermore, Tinospora rumphii leaf extract shows the most effective larvicide among the various plant extracts with the percentage mortality of $90 \%$ and $93 \%$ in 24 and 48 hours of exposure respectively.

It has been reported that the petroleum ether extract of Rhinacanthus nasutus possessed larvicidal effect with $\mathrm{LC}_{50}$ values between 3.9 and $11.5 \mathrm{mg} / \mathrm{L}$ and Derris elliptica showed $\mathrm{LC}_{50}$ values between 11.2 and $18.84 \mathrm{mg} / \mathrm{L}$ against Aedes aegypti, Culex quinquefasciatus, Anopheles dirus and Mansonia uniformis (Komalamisra et al., 2000). Karmegan et al., (1997) reported that the ethanolic extract of Jatropha curcas resulted to $100 \%$ acute mortality each at 1000 , 500, and 250ppm against Culex quinquefasciatus larvae.

The essential oil of aqueous solutions of the stalks and leaves of Croton argurophylloides, Croton nepetaefolius, Croton sondenanus and Croton zehntnen showed 100\% mortality at $50 \mathrm{ml}$ against Aedes aegypti. (Lima et al., 2006).

The oil from Cinnamomum camphora, Boswellia carteri, Anethum graveolens and Myrtus communis showed $100 \%$ mortality at $50 \mathrm{ppm}$ within 3 hours against the $3^{\text {rd }}$ instar larvae of Aedes aegypti (Amer and Mehlhorn, 2006). In the present study Pseudocedrela kotschyi exhibited a moderate larvicidal activity against Culex quinquefasciatus $\quad\left(\mathrm{LD}_{50}=630.95 \mathrm{mg} / \mathrm{ml}\right)$, and the percentage mortality for the highest concentration after 24 hours was $66.67 \%$. 
Fig.1 Probit Mortality/ Log Concentration Graph of C. quinquefasciatus Larvae After 24 Hours

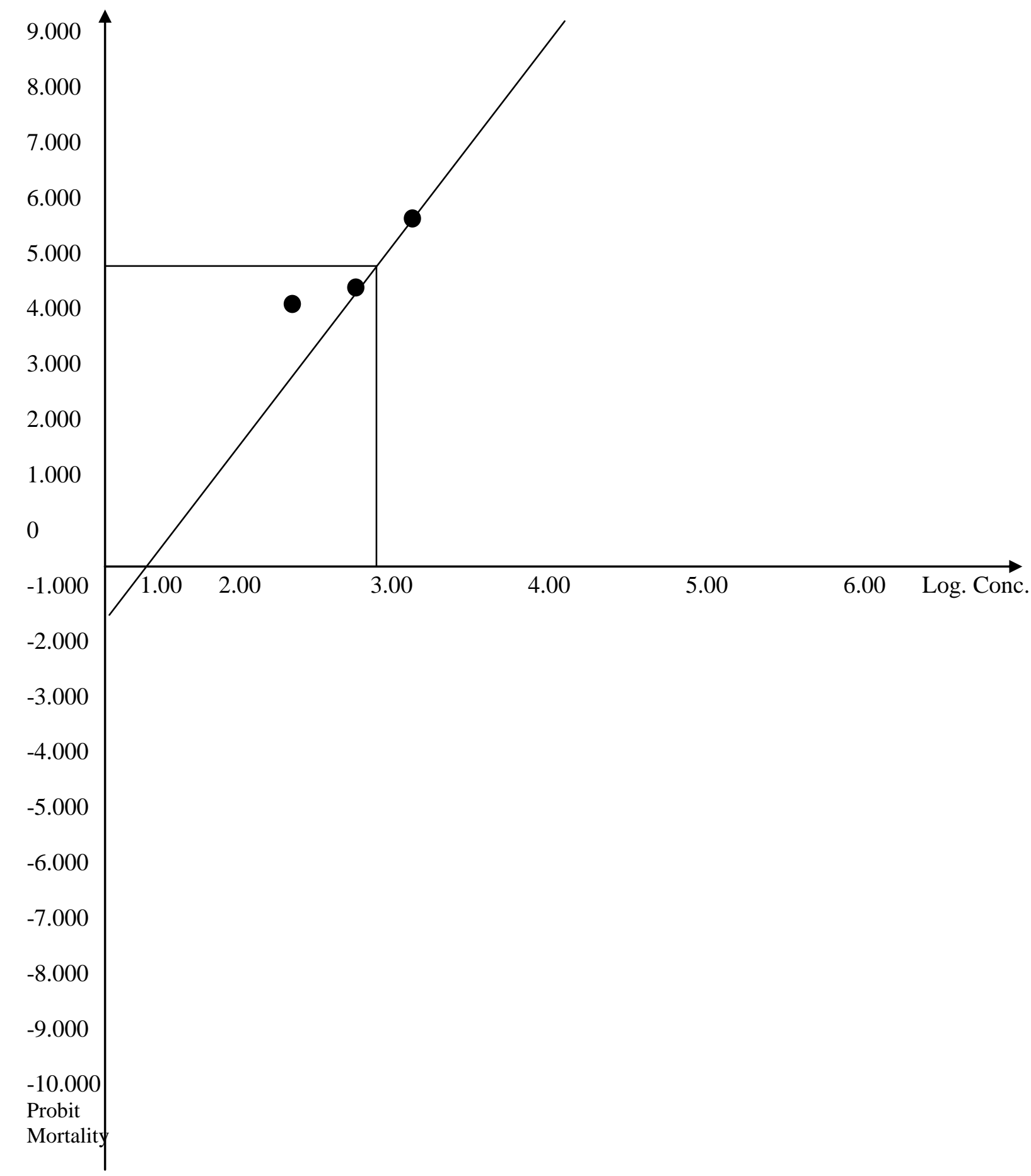

Log conc. $=2.81 ;$ Antilog of $2.81=630.95 ; \mathrm{LD}_{50}=630.95 \mathrm{mg} / \mathrm{ml}$ 
Plate.1 The Experimental Plant Pseudocedrela kotschyi

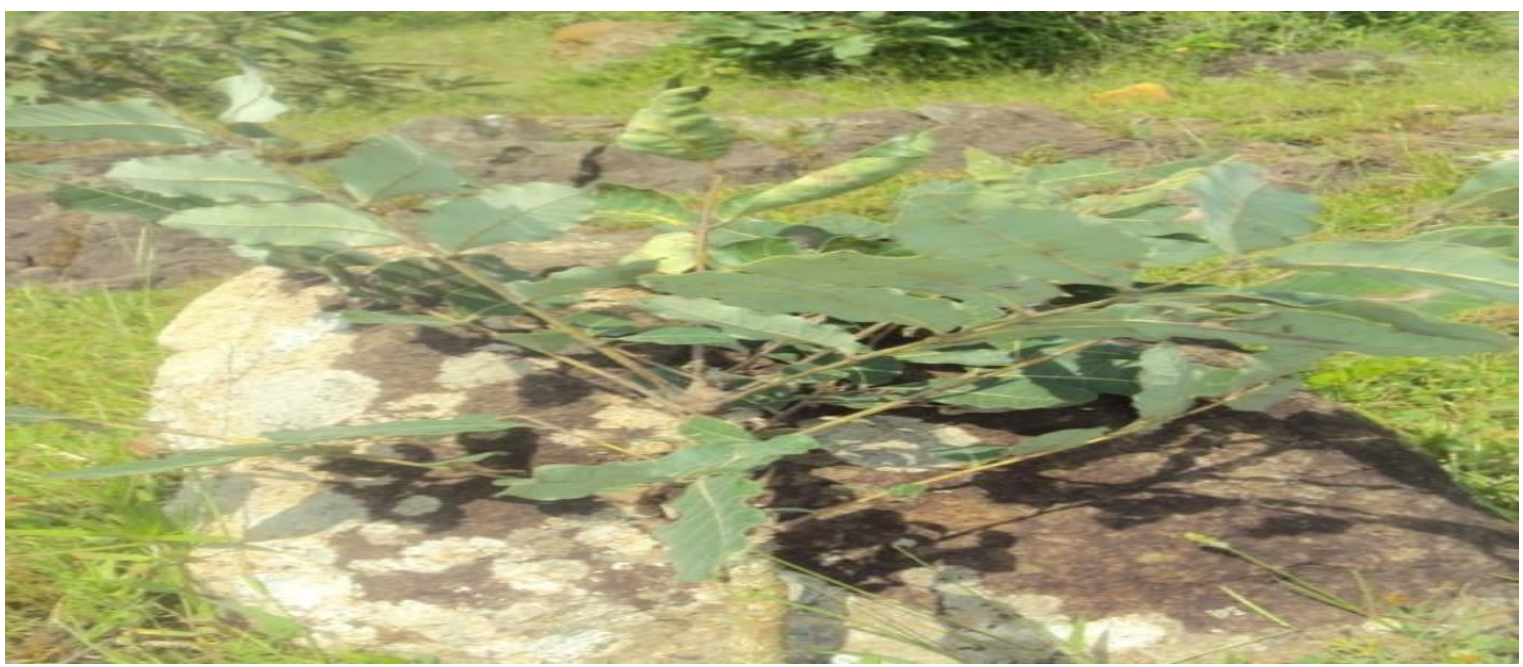

Plate.2 Experimental Set up Showing Culex quinquefasciatus in Plastic Containers

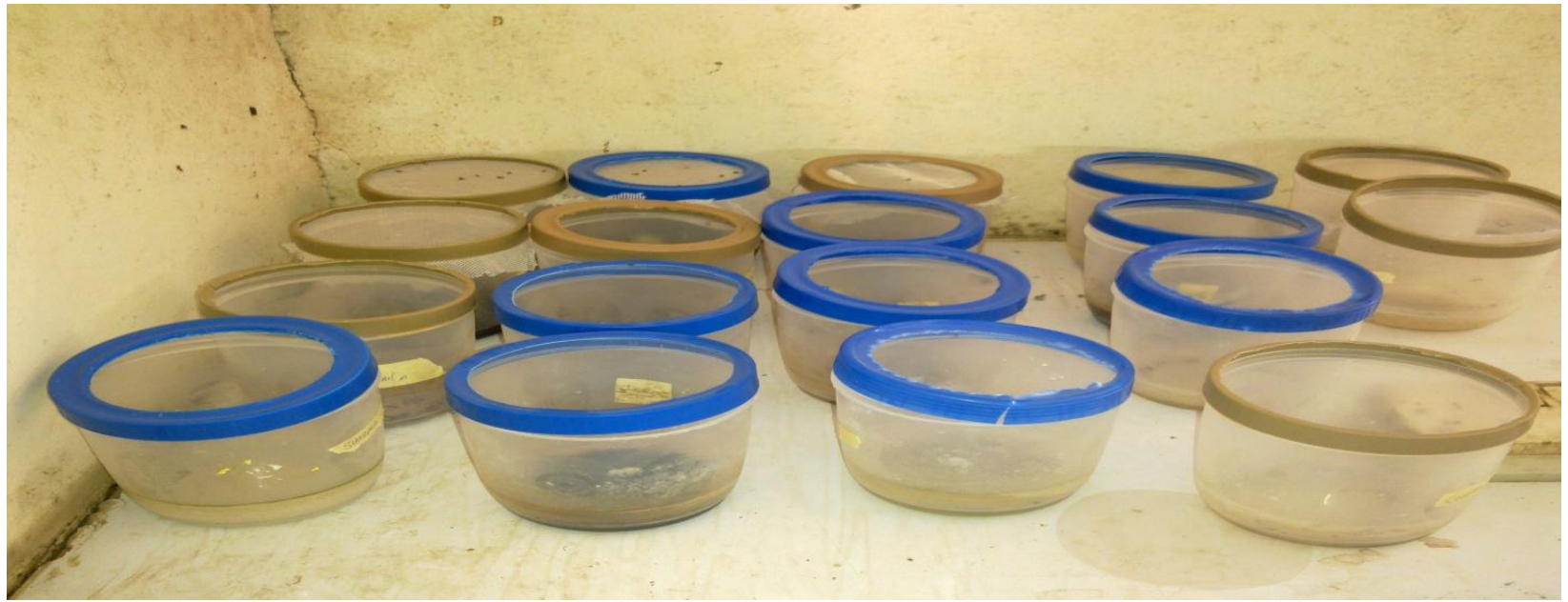

Plate.3 Experimental Set up Showing Maize Infested with Sitophilus zeamais in Plastic Containers

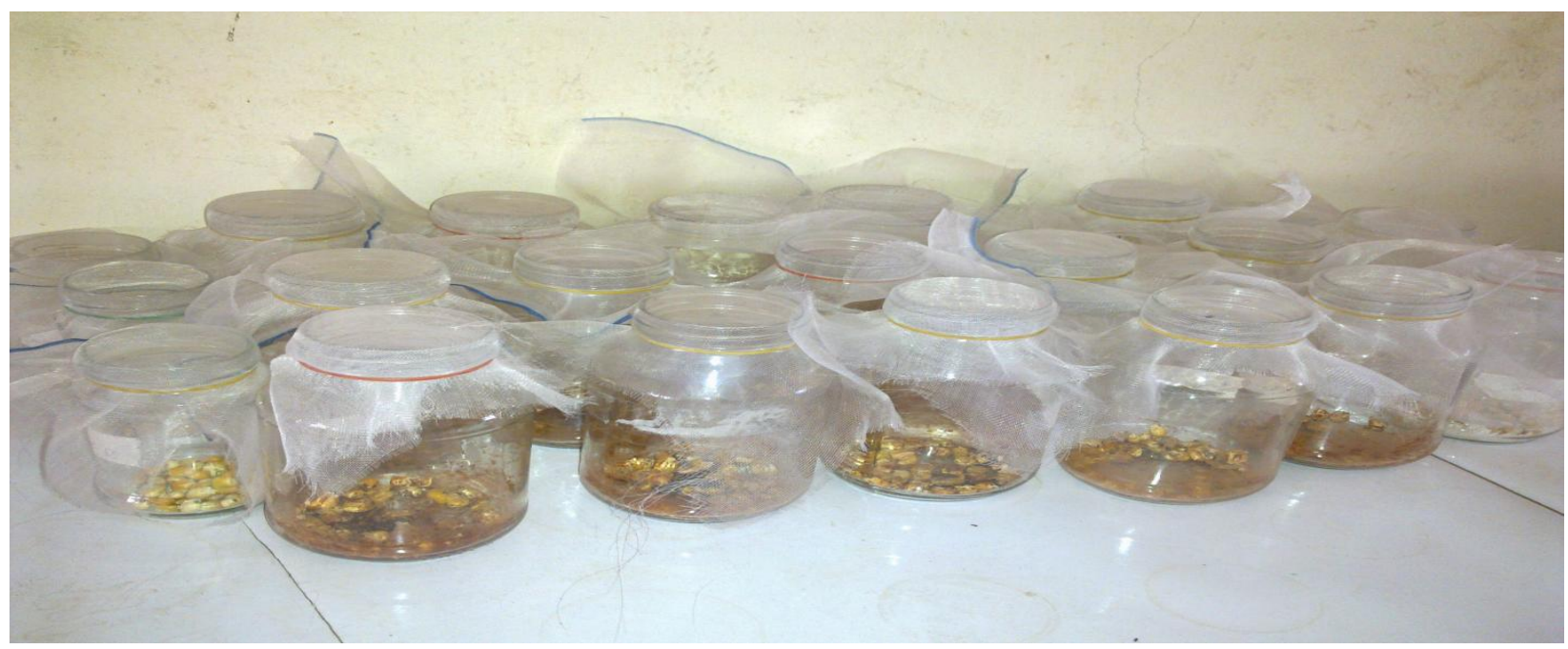


Table.1 Probit Mortality of Culex quinquefasciastus Larvae After 24 Hours

\begin{tabular}{lccccc}
\hline CONC. Mg/ml & No. of larvae & $\begin{array}{c}\text { Mean } \\
\text { mortality after } \\
24 \text { hrs }\end{array}$ & $\begin{array}{c}\text { Percentage } \\
\text { mortality }\end{array}$ & $\begin{array}{c}\text { Log } \\
\text { concentration }\end{array}$ & $\begin{array}{c}\text { Probit } \\
\text { mortality }\end{array}$ \\
\hline 1000 & 20 & 13.33 & 66.67 & 3.00 & 5.4316 \\
250 & 20 & 4.00 & 20.00 & 2.39 & 4.1584 \\
125 & 20 & 3.67 & 18.33 & 2.09 & 4.0884 \\
62.5 & 20 & 0.00 & 0.00 & 1.79 & 0.0000 \\
\hline
\end{tabular}

Table.2 Mortality of $C$. quinquefasciatus Larvae at Different Concentrations of the Ethanolic Extract of $P$. kotschyi After 3 days

\begin{tabular}{|c|c|c|c|c|c|c|}
\hline Conc. $\mathrm{Mg} / \mathrm{ml}$ & Replicates & $\begin{array}{l}\text { No. of } \\
\text { larvae }\end{array}$ & Mortality & & & $\begin{array}{c}\text { Total } \\
\text { mortality }\end{array}$ \\
\hline & & & Day 1 & Day 2 & Day 3 & \\
\hline \multirow{3}{*}{1000} & A & 20 & 15 & 5 & - & 20 \\
\hline & $\mathrm{B}$ & 20 & 12 & 8 & - & 20 \\
\hline & $\mathrm{C}$ & 20 & 13 & 6 & - & 19 \\
\hline \multirow[t]{3}{*}{250} & A & 20 & 4 & 3 & 5 & 12 \\
\hline & B & 20 & 5 & 4 & 4 & 13 \\
\hline & $\mathrm{C}$ & 20 & 3 & 2 & 7 & 12 \\
\hline \multirow[t]{3}{*}{125} & A & 20 & 0 & 2 & 4 & 6 \\
\hline & B & 20 & 5 & 2 & 5 & 12 \\
\hline & $\mathrm{C}$ & 20 & 6 & 0 & 5 & 11 \\
\hline \multirow[t]{3}{*}{62.5} & A & 20 & 0 & 0 & 5 & 5 \\
\hline & B & 20 & 0 & 0 & 6 & 6 \\
\hline & $\mathrm{C}$ & 20 & 0 & 0 & 4 & 4 \\
\hline \multirow[t]{3}{*}{ Standard drug } & A & 20 & 20 & - & - & 20 \\
\hline & B & 20 & 20 & - & - & 20 \\
\hline & $\mathrm{C}$ & 20 & 20 & - & - & 20 \\
\hline \multirow[t]{3}{*}{ Control } & A & 20 & 0 & 0 & 0 & 0 \\
\hline & B & 20 & 0 & 0 & 0 & 0 \\
\hline & $\mathrm{C}$ & 20 & 0 & 0 & 0 & 0 \\
\hline
\end{tabular}

Table.3 Mean Mortality of $C$. quinquefasciatus Larvae at Different Concentrations of the Ethanolic Extract of $P$. kotschyi After 3 days

\begin{tabular}{lccc}
\hline Conc. $\mathbf{M g} / \mathbf{m l}$ & $\begin{array}{c}\text { No. of larvae per } \\
\text { replicate (60/3) }\end{array}$ & $\begin{array}{c}\text { Mean } \\
\text { mortality } \pm \text { SE }\end{array}$ & $\begin{array}{c}\text { Percentage (\%) } \\
\text { mortality }\end{array}$ \\
\hline $\mathbf{1 0 0 0}$ & 20 & $19.67 \pm 0.33$ & 98.33 \\
$\mathbf{2 5 0}$ & 20 & $12.33 \pm 0.33$ & 61.67 \\
$\mathbf{1 2 5}$ & 20 & $9.67 \pm 1.86$ & 48.33 \\
$\mathbf{6 2 . 5}$ & 20 & $5 \pm 0.58$ & 25.00 \\
Standard drug & 20 & $20 \pm 0.00$ & 100.00 \\
Control & 20 & $0 \pm 0.00$ & 0.00 \\
\hline
\end{tabular}


Table.4 Mortality of sitophilus zeamais at different concentrations of the ethanolic extract of Pseudocedrela kotschyi after 7 days

\begin{tabular}{|c|c|c|c|c|c|c|c|c|c|c|}
\hline \multirow{2}{*}{$\begin{array}{l}\text { Conc. } \\
\text { Mg/ml }\end{array}$} & \multirow{2}{*}{$\begin{array}{l}\text { Replicat } \\
\text { es }\end{array}$} & \multirow{2}{*}{$\begin{array}{l}\text { No. of } \\
\text { weevils }\end{array}$} & \multicolumn{7}{|c|}{ Mortality of sitophilus zeamais } & \multirow{2}{*}{$\begin{array}{l}\text { Total } \\
\text { mortality }\end{array}$} \\
\hline & & & Day 1 & Day2 & Day3 & Day4 & Day5 & Day6 & Day7 & \\
\hline \multirow[t]{3}{*}{1750} & A & 10 & 0 & 0 & 1 & 1 & 0 & 1 & 2 & 5 \\
\hline & B & 10 & 0 & 0 & 1 & 0 & 1 & 0 & 1 & 3 \\
\hline & $\mathrm{C}$ & 10 & 0 & 3 & 0 & 1 & 0 & 2 & 1 & 7 \\
\hline \multirow[t]{3}{*}{1500} & A & 10 & 0 & 2 & 0 & 1 & 1 & 2 & 3 & 9 \\
\hline & B & 10 & 1 & 2 & 0 & 0 & 0 & 0 & 0 & 3 \\
\hline & $\mathrm{C}$ & 10 & 0 & 0 & 0 & 0 & 1 & 1 & 0 & 2 \\
\hline \multirow[t]{3}{*}{1200} & A & 10 & 0 & 0 & 0 & 0 & 0 & 1 & 4 & 5 \\
\hline & B & 10 & 0 & 0 & 1 & 1 & 1 & 2 & 0 & 5 \\
\hline & $\mathrm{C}$ & 10 & 0 & 0 & 1 & 0 & 0 & 0 & 1 & 2 \\
\hline \multirow[t]{3}{*}{750} & A & 10 & 0 & 0 & 0 & 0 & 3 & 0 & 0 & 3 \\
\hline & B & 10 & 0 & 0 & 0 & 1 & 3 & 4 & 1 & 9 \\
\hline & C & 10 & 0 & 1 & 2 & 1 & 0 & 0 & 0 & 4 \\
\hline \multirow[t]{3}{*}{500} & A & 10 & 0 & 0 & 0 & 0 & 0 & 0 & 2 & 2 \\
\hline & B & 10 & 0 & 2 & 0 & 0 & 0 & 2 & 0 & 4 \\
\hline & $\mathrm{C}$ & 10 & 0 & 1 & 1 & 1 & 0 & 0 & 1 & 4 \\
\hline \multirow{3}{*}{$\begin{array}{l}\text { Standar } \\
\text { d drug }\end{array}$} & A & 10 & 10 & - & - & - & - & - & - & 10 \\
\hline & B & 10 & 10 & - & - & - & - & - & - & 10 \\
\hline & $\mathrm{C}$ & 10 & 10 & - & - & - & - & - & - & 10 \\
\hline \multirow[t]{3}{*}{ Control } & A & 10 & 0 & 0 & 0 & 0 & 0 & 0 & 0 & 0 \\
\hline & B & 10 & 0 & 0 & 1 & 0 & 0 & 1 & 0 & 2 \\
\hline & $\mathrm{C}$ & 10 & 0 & 0 & 0 & 1 & 0 & 1 & 1 & 3 \\
\hline
\end{tabular}

Table.5 Mean Mortality of Sitophilus zeamais

\begin{tabular}{llll}
\hline Conc. $\mathbf{M g} / \mathbf{m l}$ & $\begin{array}{l}\text { No. of weevils per } \\
\text { replicate(30/3) }\end{array}$ & Mean mortality $\mathbf{\pm S E}$ & $\begin{array}{l}\text { Percentage(\%) } \\
\text { mortality }\end{array}$ \\
\hline $\mathbf{1 7 5 0}$ & 10 & $5 \pm 1.15$ & 50.00 \\
$\mathbf{1 5 0 0}$ & 10 & $4.67 \pm 2.19$ & 46.67 \\
$\mathbf{1 2 0 0}$ & 10 & $4.00 \pm 1.00$ & 40.00 \\
$\mathbf{7 5 0}$ & 10 & $5.33 \pm 1.86$ & 53.33 \\
$\mathbf{5 0 0}$ & 10 & $3.33 \pm 0.67$ & 33.33 \\
Standard drug & 10 & $10 \pm 0.00$ & 100.00 \\
Control & 10 & $1.67 \pm 0.88$ & 16.67 \\
\hline
\end{tabular}

From this study, it has been observed that Pseudocedrela kotschyi demonstrated moderate to high effect on the mosquito larvae and low effect on the maize weevil. This is at variance with Adeniyi et al., (2010) who reported no appreciable effect of Pseudocedrela kotschyi on Streptococcus mutans and Staphylococcus aureus. There were no zones of inhibition at all concentrations tested. The results of this study is not consistent with Azokou et al., (2013) who investigated the larvicidal activities of 45 plants including $P$. kotschyi, traditionally used in Côte d'Ivoire. Of the 49 ethanol crude extracts 7 (14.29\%) showed high activity against III and IV instar larvae of Anopheles gambiae and Culex quinquefasciatus at 1000 ppm $24 \mathrm{~h}$ post-exposure. These seven extracts were obtained from six plant species: Cissus populnea, Cochlospermum planchonii, Heliotropium indicum, Phyllanthus amarus, Vitex grandifolia and Alchornea cordifolia. However, three most active plant species $($ LC50 $=80-180 \mathrm{ppm})$ were Cs. populnea, Cm. planchonii and $P$. amarus. Six of the extracts had effect on viability of susceptible and resistant larvae of Anopheles, resulting in death of larvae. 
The effect of Pseudocedrela kotschyi on the mortality of Sitophilus zeamais shows that there is no significant difference ( $p>0.05)$. However, to date, numerous plant extracts are shown to possess strong feeding deterrent (Arnason et al., 1987) and mortality activity. In this study it can be stated that Pseudocedrela kotschyi have very low effect on Sitophilus zeamais compared with Culex quinquefasciatus.

The report of this study is consistent with Yakubu et al., (2015) who reported that the ethanol stem bark extract of $P$. kotschyi reduced the activities of D. maculatus larvae and adult in feeding and movement within infested fish samples during the days of exposure, suggesting that the plant possesses potential insecticidal properties although low mortality of $D$. maculatus larvae and adults were recorded at varying concentrations. This study corroborates with Boussaada et al., (2008) who reported that larval growth inhibition of flour beetle Tribolium confusum was significantly induced by methanolic and ethyl acetate extracts of Mantisalca duriaei and petroleum ether, chloroformic and methanolic extracts of Rhaponticum acaule. Larvae appeared to be more sensitive than adults which reached respectively $83 \%$, $77 \%$ by using petroleum ether and methanol extracts of $R$. acaule.. These adults gave $33 \%$ mortality after sixteen days when $R$. acaule petroleum ether was applied.The extracts of the four plants commonly used in traditional medicine in Morroco disrupted the developmental cycle of Tribolium castaneum was reported by Jbilou et al., (2006). Significant insecticidal activity against $T$. castaneum larvae and adults was observed with crude methanol extract from $P$. harmala, followed by extracts of A. iva, Ari. baetica and $R$. raphanistrum. The larvae were more susceptible than adults to extracts of Ari. baetica and $R$. raphanistrum.In the manner, Souza et al., (2010) observed that the extracts assy of Tapirira guianensis, Schinus terebinthifolius, Tabebuia heptaphylla and Gomphrena elegans against Sitophylus zeamais using wheat grains, showed no mortality during the first two days. Significant differences from the fifth day and become more pronounced on the tenth day. $T$. guianensis extracts produced the lowest mortality of $13 \%$, followed by S. terebinthifolius with $18 \%$ mortality and $T$. heptaphylla which gave $35 \%$ mortality. All extracts of G. elegans led to mortality rates ranging from $36 \%$ to $46.55 \%$ only on the tenth day.

However, the results of this study is at variance with Sha-sha et al., (2012) who observed that the essential oils of Artemesia giraldii and Artemesia subdigitata flowering aerial parts exhibited contact toxicity against
Sitophilus zeamais adults with $\mathrm{LD}_{50}$ values of $40.51 \mu \mathrm{g} /$ adult and $76.34 \mu \mathrm{g} /$ adult, respectively. Othira $e t$ al., (2009) reported that at a concentration of $2 \mu \mathrm{L}$ air, Hyptis oil caused 68\% mortality of Sitophilus zeamais in 2 days. The variation could probably be due to concentration of the extracts which at low rate may not be effective or the phytochemical composition of the plant extracts might contained active ingredients which may affect insects according to species and stages or the physiology of the adults weevils which might have develop some resistance due to constant exposure to pesticides.

From the research, it suggests that Pseudocedrela kotschyi extract significantly exhibited more insecticidal effect on Culex quinquefasciatus larvae than no the Sitophilus zeamais. Therefore, the effect of the plant extract on the larvae and their potential local availability make it attractive candidate for biopesticides.

\section{References}

Adedire, C.O. and Lajide, L. (2003). Ability of extracts of ten tropical plant species to protect maize grains against infestation by the maize weevil, sitophilus zeamais during storage. Nigeria Journal of Experimental Biology, 4(2): 175-179.

Adeniyi, C.B.A., Odumosu, B.T., Aiyelaagbe, O.O. and Kolude, B. (2010). In-vitro antimicrobial activities of methanol extracts of Zanthoxylum xanthoxyloides and Pseudocedrela kotschyi. African Journal of Biomedical Research (13):61-68.

Amer, A.and Mehlhorn, H. (2006) persistency of larvicidal effects of plant oil extracts under different storage conditions. Parasitological Research 99:473-477.

Arannilewa, S. T. (2002). Assessment of the insecticidal properties of four plant extracts as protectants against the cowpea bruchid Callosobruchus maculatus (F.) (Coleoptera :Bruchidae). Annals of Agricultural Sciences, 3,49-45.

Arnason, J.T., Philogene, D.J.R., Donskov, N. and Kubo, I. (1987). Limonoids from the maliaceae and Rutaceae family to reduce feeding, growth and development of Ostrinia nubilalis. Entomologia Expermentalis et Applicata 43: 221-226.

Azokou, A., Kone, M. W., Koudou, B. G.and Tra Bi, H. F. (2013). Larvicidal potentialof some plants from West Africa against Culexquinquefasciatus (Say) and Anopheles gambiae Giles (Diptera: Culicidae). Journal of Vector Borne Diseases,50: 103-110. 
Bernhard, L., Bernhard, P. and Magnussen, P. (2003). Management of patients with lymphoedema caused by filariasis in north-eastern Tanzania, Alternate Approaches: Physiology89: 743-749.

Borro, D. J. \& Delong, D. M. (1964). An Introduction to the study of insect. Constable and Company Ltd. 10 Orange Street, London W. C. 2.Pp. 819.

Boussaada, O., Kamel, M. B. H., Ammar, S., Haouas, D., Mighri, Z. and Helal, A. N. (2008). Insecticidal activity of some Asteraceae plant extracts against Tribolium confusum. Bulletin of Insectology, 61 (2): 283-289.

Cosimi, S., Rossi, E., Coini, P. L. and Canale, A. (2009) boiactivity and qualitative analysis of some essential oils from Mediterranean plants against storedproducts pest: evaluation of repellency against Sitophilus zeamais motschulsky, Cryptotestes ferugineus (Stephens) and Tenebrio moletor (L). Journal of Stored Products Research45: 125-132.

Dawet, A., Yakubu, D. P. \& Igwebike, E. A. (2011).Trypanocidal activity and haematoxicity ofPseudocedrela kotschyi Harms (Meliaceae) ethanolic stem bark extract in Trypanosoma brucei infected rats. Biological \& Environmental SciencesJournal for the Tropics, 8(1), $137-142$.

Gutierrez, P. M., Antepuesto, A. N., Eugenio, B. A. L. and Santos, M. F. L. (2014). Larvicidal Activity of Selected Plant Extracts against the Dengue vector Aedes aegypti Mosquito. International Research Journal of Biological Sciences, 3(4): 23-32,

Hill, D. S. (1975). Agricultural insect pests of the tropics and their control. Cambridge University Press London. 516 PP.

Huang, F. and Subramangam, B. (2005). Management of Stored- product insects in wheat in pririmiphosmethyl and pirimiphos-methyl plus. Synergized Pyrethrins Pest Management Science, 61: 356-362.

Isman M.B. (2006). The role of botanical insecticides deterrents and repellents in modern agriculture and an increasing regulated world. Annual review of entomology; 51: 45-66.

Jbilou, R., Ennabili, A. and Sayah, F. (2006). Insecticidal activity of four medicinal plant extracts against Tribolium castaneum (Herbst) (Coleoptera: Tenebrionidae). African Journal of Biotechnology, 5 (10): 936-940

Karmegam, N., Sakthivadivel, M., Anuradha, V. and Daniel, T. (1997). Indigenous plant extracts as larvicidal against Culex quinquefasciatus. Bioresearches Technology,59(2-3);137-140.

Kassim O.O, Loyevsky M, Amono H, Lashley L, Akonai K.A, Gordeuk VR (2009). Inhibition of in-vivo growth of Plasmodium faciparum by Pseudocedrela kotschi extract alone and in combination with Fagara zanthoxyloides extract. Social Tropical Medical Hygiene 103: 698-702

Komalamisra, N., Trongtokit, Y. and Apwathnasorn, C. (2000). Screening for larvicidal activity in some Thai plants against four mosquito vector species. South East Asia Journal of Tropical Medical Public Health,36(6):1412-1422.

Lima, M.G., Maia, I.C., Sousa, B.D. and Freitas, S.M. (2006). Effect of stalk and leaf extract from Eurphorbiaceae species on Aedea aegypti larvae. Revised Instruction on Medicine in Tropical Sao Paulo,48(4):211-214.

Maga, N, Hope, R Cairns, V, Aldred, D. (2003). Post harvest fungal ecology impact of fungal growth and mycotoxin accumulation in stored grains. Environmental Journal of Plant Pathology,109: 723-730.

Mankale, B (2010). The larvicidal effect of Neem Tree (Azadirachta indica) on Culex quinquefasciatus. (Unpublished material).p 42-43.

Maxwell, C. A., Curtis, C. F., Haji, H., Kisumku, S., Thalib, A. I. and Yahya, S. A. (1990). Control of bancroftian filariasis by integrating therapy with vector control using polystyrene beads in wet pit latrines. Transaction of Royal Society of Tropical Medicine and Hygiene. 84:709-14.

Oliver-Bever B. (1986). Medicinal plants of Tropical West Africa. Cambridge University Press. London. pp164.

Othira, J.O., Onek, L.A., Deng, L.A. and Omolo, E.O. (2009). Insecticidal potency of Hyptis spicigera preparations against Sitophilus zeamais and Trobolium castaneum on stored maize grains. African Journal of Agricultural Research,4(3):187192.

Pauela R. (2007). Possibilities of botanical insecticides exploitation in plant protection. Pest Technology1:47-52.

Pest Web (2010). Greater rice weevil. http://agspsrv34.agric.wa.gov.au/ento/pestweb/quer $y 1-1$.

Pimentel, D. (2007). Area-wide pest management, environmental, economic and food issues. In (Ureysen, R.A.S., Hendrichs M.J.B. (eds)), Area wide control of insect pests (pp. 35-47). Netherlands: Springer.

Ramarah K.D., Das P.K, Micheal E., Guyatt H. (2000). The economic burden of lymphatic filaiasis in India. Parasitology Today, 16(6):251-253. 
Sha-sha, C.,Zhi-long, L., Shu-shan, D. and Zhi-wei, D. (2012). Molecules, (17):7255-7265.

Souza, A. P., Marques, M. R., Mahmoud, T. S., Bolzani, V. S., Caputo, B. A., Canhete, G. M., Leite, C. B. and De Lima, D. P. (2010). Insecticidal effect of extracts from Native Plants to Mato Grossodo Sul, Brazil, on Sitophilus zeamais Mots (Coleoptera: Curculionidae). BioAssay, 5: 1-5.

Taubes, G., (1997). A mosquito bites back. New York times magazine, August 24, pp. 40-46,
Yadouléton, A., Badirou, K., Agbanrin, R., Jöst, H., Attolou, R., Srinivasan, R., Padonou, G. and Akogbéto, M. (2015). Insecticide resistance status in Culex quinquefasciatus in Benin.Parasites \& Vectors. doi: 10.1186/s13071-015-0638-3.

Yakubu, D. P., Dawet, A., Allan, A. I. and Nwibari, B, M, W. (2015). Insecticidal effects of the ethanolic extract of Pseudocedrela kotschyi against Dermestes maculatus (Coleoptera: Dermestidae) ontreated dried catfish (Clarias gariepinus). FULafia Journal of Science and Technology 1(1): 17-21.

\section{How to cite this article:}

Dawet A., D. P. Yakubu and Meshach T. M. 2017. Studies on the Insecticidal Activities of Pseudocedrela kotschyi on Culex quinquefasciatus Larvae and the Maize Weevil (Sitophilus zeamais) Motschulsky. Int.J.Curr.Res.Aca.Rev. 5(11), 58-68. doi: https://doi.org/10.20546/ijcrar.2017.511.011 